obtained from the honorary secretary of the Manchester Section of the Society, Dr. W. H. Brindley, c/o Hardman and Holden, Ltd., Manox House, Miles Platting, Manchester 10.

\section{Fourteenth International Veterinary Congress}

THE Fourteenth International Veterinary Congress will be held in London during August 8-13, and the meeting will take place in the Central Hall, Westminste, and in Church House, Westminster (see Natyle, February 5, p. 205). It is now known that H R.H. The Duke of Gloucester will be unable to open the Congress. The main theme of the Congress is the veterinary profession's contribution to world food supplies, and at the plenary meetings in the Central Hall the first address will be given by Lord Boyd Orr on "The World Food Situation". At the sectional meetings, papers (printed and circulated in advance) will be presented by delegates, from many parts of the world, who will discuss animal health and disease control problems. Further information on the International Congress may be obtained from the Organising Secretary, Fourteenth International Veterinary Congress, 10 Red Lion Square, London, W.C.1.

The National Veterinary Medical Association will this year confine its annual congress activities to three days, two of which will coincide with meetings of the International Congress, so that there may be joint discussions; the third day will be devoted largely to demonstrations at the Royal Veterinary College, Camden Town, London, N.W.I. The Association congress will afford opportunities for international discussion on small-animal matters, as opposed to the farm livestock subjects which will occupy the time of delegates during the first four days.

\section{Traditional Art of the British Colonies}

AN exhibition of "Traditional Art of the British Colonies" will be opened at the Royal Anthropological Institute, 21 Bedford Square, London, W.C.1, on June 21 , and will remain open throughout the "Colonjal Month", of which it is one of the principal featyres, and will be open between the hours of 10 , .m. and 7 p.m. on Mondays to Saturdays, closing on Wednesday, July 20. This will be an unusual opportunity for studying the ancient cultures of Nigeria, as well as masks and figures from other African Colonies, from Malaysia and from Oceania. A full descriptive and illustrated catalogue (price 1s. $6 d$. to visitors) underlines the relevance of the scientific data of anthropology to æsthetic apprecia. tion.

\section{Special Science Exhibition for the Blind}

THE first exhibition in Great Britain solely for blind persons is being held at the Science Museum, South Kglsington, London, S.W.7, during June 11-26. It has been organised by the Science Museum in conjanction with the National Institute for the Blind and suitable exhibits covering a wide range of popylar science are available for examination by blihd visitors. The exhibition includes models and apparatus relating, for example, to the many forms of transport (railways, shipping and aircraft), to mining, the textile industries, hand and machine tools, time measurement, meteorology, printing and typewriting. Descriptive labels, transcribed into Braille, explain the exhibits, and printed labels are available for escorts to read to those not pro- ficient in Braille. As the Exhibition is intended solely for the blind and partially sighted, it is not open to normally sighted members of the public unless acting as escorts to blind visitors. The Exhibition is free and is open daily from 10 a.m. until 6 p.m. (Sundays $2.30-6$ p.m.).

\section{Lady Tata Memorial Fund Awards}

LADX TAy MEMorial Fund international awards for research in blood diseases, with special reference to leukghia, have been awarded for the year 1949-50 to the following, for work at the places mentioned. Grants for research expenses and assistance: Dr. M. C. Bessis (Paris); Dr. J. Bichel (Aarhus); Dr. P. Cazal (Montpellier) ; Dr. J. Clemmesen (Copenhagen); Dr. E. Kelemen (Szeged); Dr. J. Chandra Mehta (Agra); Prof. C. Oberling (Paris); Dr. Edith Paterson (Manchester); Dr. G. Schallock (Münster); Prof. E. Storti (Pavia). Scholarships : Dr. P. Atanasiu, of Rumania (Paris); Dr. C. F. M. Plum (Copenhagen).

\section{University of London: Appointments}

THE following appointments in the University of London hay been announced: Mr. R. S. Edwards, to the University chair of economics with special referenge to industrial organisation tenable at the London School of Economies and Political Science as from October 1 ; Dr. G. A. D. Haslewood, to the Yhiversity chair of biochemistry tenable at Guy's Hospital Medical School as from October 1. The title of reader in mathematics in the University has been conferred on Dr. Daniel Pedoe, in respect of the post held by him at Westfield College. The following doctorates have been conferred: D.Sc. : H. J. S King (Northern Polytechnic), F. O. Howitt (West Ham Municipal College) and B. C. Saunders (an external student).

\section{Announcements}

Mr. T/Dalling, ehief veterinary officer, Ministry of Agriculture and Fisheries, has been elected pregident of the Royal College of Veterinary Surgeons for the year 1949-50.

A symposium on "Photochemistry in Relation to Textiles" is being arranged by the Society of Dyers and Colourists and will be held at Harrogate during September 22-24. At this symposium, which is open to non-members, special emphasis will be laid on the scientific and technical aspects of the fading of dyed materials and the photodegradation of both dyed and undyed materials. Further infommation may be obtained from the Assistant Secretary, Society of Dyers and Colourists, 32-34 Piccadilly, Bradford, Yorks.

THE Department of Radiology of the University of Caljornia Medical School will be holding a postgradyate course on physics in radiation therapy duyng September 6-9, after the course on the medical aspects of nuclear energy during August 29-September 3 (see Nature, May 14, p. 760). The course will be conducted under the chairmanship of Dr. Robert S. Stone, professor of radiology, and ten lectures will be delivered by Dr. Edith H. Quimby, associate professor of radiology, Columbia University. Ionizing radiations from various types of sources will be considered. Further information may be obtained from Prof. Stacy R. Mettier, Medical Extension, University of California Medical Center, San Francisco 22, California. 